\title{
KAJIAN SOSIOLOGI HUKUM TERHADAP ADAT KEWARISAN MASYARAKAT DESA MANGKUNG KECAMATAN PRAYA BARAT KABUPATEN LOMBOK TENGAH
}

\section{Lalu Junaidi}

\begin{abstract}
Abstrak
Hukum waris merupakan salah satu bagian hukum kekeluargaan, karena ruang lingkup pembahasannya menyangkut tentang proses pelaksanaan pengalihan harta benda orang yang sudah meninggal kepada anggota keluarga yang masih hidup. Dalam pembagian harta warisan banyak bentuk hukum yang mengaturnya, seperti halnya hukum Islam, hukum positif dan hukum adat yang berkembang di kalangan kehidupan masyarakat. Hukum yang digunakan masyarakat Desa Mangkung lebih dominan memilih hukum adat ketimbang hukum-hukum lainnya.

Adapun yang menjadi pokok pembahasan dalam skripsi ini adalah bagaimana proses pelaksanaan adat kewarisan masyarakat Desa Mangkung Kecamatan Praya Barat Kabupaten Lombok Tengah, dan mengapa masyarakat Desa Mangkung lebih memilih menggunakan hukum adat dalam melakukan pembagian harta warisan. Penelitian ini termasuk penelitian lapangan (field research), yaitu penelitian yang secara langsung ke lokasi penelitian untuk melakukan sebuah pengamatan tentang fenomena-fenomena yang diteliti di lokasi penelitian didukung dengan wawacanra dengan pihak-pihak yang terkait. Pendekatan penelitian yang digunakan adalah pendekatan kualitatif yang bermaksud untuk memahami fenomena tentang apa yang dialami oleh pelaku di lokasi penelitian baik dari segi prilaku, persepsi, motivasi, tindakan dengan cara deskripsi dalam bentuk kata-kata dan bahasa.

Hasil penelitian yang diperoleh menjelaskan bahwa, pembagian harta warisan yang sifatnya terbagia hanya diberikan kepad ahli waris anak laki-laki, dan harta warisan yang sifatnya tidak terbagi hanya diberikan kepada ahli waris laki-laki paling kecil untuk dimiliki secara pribadi. Sedangkan anak perempuan hanya diperbolehkan membawa harta yang ada di anggota badan, seperti kalung, cincin dan giwang yang tidak termasuk dalam harta bersama dalam keluarga, melainkan hak milik pribadi secara sah.
\end{abstract}


Ada beberapa alasan masyarakat Desa Mangkung menggunakan hukum adat dalam melakukan pembagian harta warisan diantaranya, karena masyarakat setempat hanya bisa mengikuti kebiasaan masyarakat sebelumnya, dan masyarakat Desa Mangkung lebih memilih untuk menempuh jalan penyelesian yang lebih cepat dengan cara musyawarah dan mufakat untuk memperoleh kesepakatan anatar sesama ahli waris demi kebaikan dalam upaya menghindari perselisihan dalam hubungan keluarga.

Kata kunci: Adat Kewarisan Desa Mangkung.

\section{A. Pendahuluan}

Hukum waris atau yang lazimnya disebut ilmu fara'id. Dalam literatur hukum Islam adalah salah satu bagian dari keseluruhan hukum Islam yang mengatur tentang peralihan harta dari orang yang telah meninggal kepada keluarganya yang masih hidup. ${ }^{1}$

Dan hukum waris merupakan salah satu bagian terkecil dari hukum keluarga, karena sangat erat kaitannya dengan ruang lingkup kehidupan manusia, sebab setiap manusia pasti akan mengalami pristiwa hukum yang dinamakan kematian. Hal ini yang akan mengakibatkan masalah tentang bagaimana penyelesaian hak-hak dan kewajiban terhadap anggota keluarga yang ditinggalkan. ${ }^{2}$

Hukum waris menduduki tempat yang sangat penting dalam

\footnotetext{
${ }^{1}$ Amir Syarifuddin, Hukum Kewarisan Islam (Jakarta: Prenada Media, 2014), h. 16.

${ }^{2}$ Keluarga Besar Peradilan Agama (KBPA), "Hukum Kewarisan Menurut Hukum Perdata (BW) dan KHI”, http:/ / www.uinjkt.blogspot.com. (Diakses, 11 April 2006).
}

hukum Islam. Al-Qur'an mengatur dengan jelas dan terprinci, karena kematian pasti akan dialami oleh setiap orang, dan dari kematian seseorang akan menimbulkan sebab berlakunya aturan hukum kewarisan terhadap keluarga dan harta benda yang ditinggalkanya. ${ }^{3}$

Sebab itu Islam mengatur cara pembagian masing-masing ahli waris baik itu laki-laki maupun perempuan yang sudah ada ketentuannya dalam Al-Qur'an, sebagaimana yang tertera dalam Firman Allah SWT.

Ayat di atas menjelaskan bahwa ahli waris pihak laki-laki dan perempuan mempunyai hak atas harta peninggalan ibu bapak dan kerabatnya yang meninggal, dan manusia sebagai hamba Allah SWT wajib mematuhi serta menjalankan ketentuan hukum yang sudah ditetapkan.

${ }^{3}$ Idris Ramulyo, Perbandingan Hukum Kewarisan Islam di Pengadilan Agama dan Kewarisan Menurut Undang-Undang Hukum Perdata (BW) di Pengadilan Negeri (Jakarta: Pedoman Ilmu Jaya, 1992), h . 6. 
Walaupun hukum kewarisan sudah diatur dalam Islam dengan jelas, namun dalam kenyataannya di masyarakat masih belum tersosialisasi dengan baik. Hal ini tidak bisa lepas dari pengaruh Indonesia yang penduduknya memiliki beraneka ragam bentuk kebudayaan yang mencakup pengetahuan, kepercayaan, kesenian, moral, dan adat-istiadat. Dari bergam bentuk kebudayaan inilah yang mengakibatkan masyarakat tidak memiliki satu bentuk hukum, melainkan banyak bentuk hukum yang berkembang dan sifatnya mengikat dan merubah masyarakat.

Salah satunya adalah hukum adat, yang dimana merupakan salah satubentuk hukum yang sifatnya tidak tertulis, melainkan bentuk hukum yang timbul akibat suatu kebiasaan yang dilakukan oleh masyarakat yang sulit untuk ditinggalkan, dan dari kebiasaan tersebut akan timbul satu bentuk hukum yang akan mempengaruhi dan mengatur dalam kehidupan masyarakat itu sendiri. ${ }^{4}$

Hukum adat yang banyak berkembang di masyarakat adalah cara pembagian harta warisan, yang dimana kebanyakan dari masyarakat lebih memilih untuk menggunakan hukum adat dalam menyelesaikan masalah terkait dengan harta

${ }^{4}$ Departemen Agama RI, Al-Qur'an dan Terjemahan, (Bandung: PT Sygma Examedia Arkanleema, 2009), h. 45. peninggalan. Hal ini dapat dilihat dari realitas pembagian harta warisan yang dilakukan oleh masyarakat Desa Mangkung yang mempunyai cara tersendiri dalam menyelesaikan masalah hukum yang berkaitan dengan harta seseorang yang meninggal dunia dengan anggota keluarganya. ${ }^{5}$

Anak laki-laki yang tertua sebagai pengganti orang tua yang telah meninggal bukanlah pemilik harta secara perorangan, melainkan hanya berkedudukan sebagai pemegang mandat orang tua yang punya kewajiban mengurus anggota keluarga yang ditinggalkan. Ahli waris anak laki-laki tertua yang mengatur sekaligus membagikan harta warisan kepada ahli waris pihak laki-laki setelah menjalani wasiat dan hutang yang berkaitan dengan muwaris, sedangkan ahli warisa anak perempuan tidak akan diberikana harta warisan Masyarakat Desa Mangkung bisa dikatakan secara keseluruhan memiliki satu keyakinan dalam beragama yakni agama Islam yang memiliki hukum syara’ sebagai pedoman utama dalam menjalani kehidupan, namun dalam kenyataannya masyarakat Desa Mangkung lebih dominan untuk memilih menggunakan hukum adat yang telah diwariskan oleh nenek moyang mereka, khususnya hukum

${ }^{5}$ Observasi di Desa Mangkung, Tanggal 12 Agustus 2016 
adat yang menyangkut persoalan tentang pembagian harta warisan. ${ }^{6}$

Walaupun dalam Islam telah dijelaskan hukum yang secara khusus mengatur tentang pembagian harta warisan, namun hal tersebut tidak bisa mempengaruhi kebiasaan yang dilakukan oleh masyarakat Desa Mangkung. Karena pembagian harta warisan yang dilakukan masyarakat Desa Mangkung merupakan salah satu bentuk kebiasaan masyarakat setempat yang sifatnya turuntemurun dari zaman nenek moyang mereka. Dan kebiasaan tersebut sudah mengakar dan menjadi salah satu bagian terkecil dari sekian banyak hukum adat yang berlaku di Desa Mangkung.

Berdasarkan uraian dari konteks penelitian di atas maka penyusun merasa tertarik untuk melakukan sebuah penelitian dan mengkaji lebih mendalam tentang fenomena hukum adat kewarisan yang berlaku di Desa Mangkung serta alasan mendasar sehingga masyarakat Desa Mangkung lebih memilih untuk menggunakan hukum adat ketimbang hukum Islam.

Adapun penelittian ini akan diimplemintasikan dalam bentuk karya ilmiah yakni skripsi dengan judul: "Kajian Sosiologi Hukum Terhadap Adat Kewarisan Masyarakat

\footnotetext{
${ }^{6}$ Burhanudin Tokoh Masyarakat Desa Mangkung, Wawancara Di Desa Mangkung. Tanggal 12 Agustus 2016
}

Desa Mangkung Kecamatan Praya Barat Kabupaten Lombok Tengah”.

\section{B. Kerangka Teori}

\section{Pengertian Sosiologi Hukum}

Sosiologi berasal dari pemaduan antara dua istilah yang awalnya digunakan secara terpisah, yakni sosiologi dan hukum. Secara terminologis yang dimaksud dengan hukum di sini bukan ilmu hukum, melainkan berbagai bentuk kaidah sosial atau norma, etika, prilaku dan sebagainya yang berfungsi mengatur kehidupan manusia dalam bermasyarakat. Dengan demikian, sosiologi hukum lebih tepat kajian ilmu sosial terhadap hukum yang berlaku dimasyarakat danprilakuserta gejala sosial yang menjadi penyebab lahirnya hukum di masyarakat. ${ }^{7}$

Menurut Soerjono Soekanto sosiologi hukum adalah suatu cabang ilmu pengetahuan yang secara analitis dan emperis dalam menganilisa atau mempelajari hubungan timbal balik antara hukum dengan gejala gejala sosial. Sedangkan menurut Satjipto Rahardjo sosiologi hukum adalah pengetahuan hukum terhadap pola prilaku masyarakat dalam konteks sosial. $^{8}$

\footnotetext{
${ }^{7}$ Beni Ahmad Saebani, Sosiologi Hukum (Bandung: Cv Pustaka Setia, 2007), h. 16.

${ }^{8}$ Zainuddin, Sosiologi Hukum, (Jakarta: Sinar Grafika, 2015), h. 1.
} 


\section{Pendekatan Sosiologi Hukum}

Ada tiga pendekatan yang yang digunakan dalam soiologi hukum untuk memahami hukum yang berlaku, hukum yang diterapkan, dan hukum yang dilaksanakan dalam kehidupan bermasyarakat. Adapun uraian dari ketiga pendekatan sosiologi hukum adalah sebagai berikut:

a. Pendekatan ontologis, yaitu pendekatan yang mengkaji secara mendalam tentang hakikat kehidupan sosial dan hukum yang diterapkan dan berlaku di masyarakat.

b. Pendekatan epistemologis yakni pendekatan yang menggunakan pilsafat ilmu yang mempersoalkan kebenaran pengetahuan. Kebenaran epeistemilogis dirinci ke dalam empat hal di antaranya:

1. Kebenaran religius, yaitu kebenaran yang dibangun oleh kadiah kaidah agama dan keyakinan tertentu yang bersifat mutlak dan tidak dapat diubah.

2. Kebenaran filosofis, yaitu kebenaran dari hasil perenungan dan pemikiran fefleksi filosof yang kontemplatif dan spekulatif.

3. Kebenaran estetis, yaitu kebenaran yang didasarkan pada unsur seni dan instrument perasaan tentang keindahan, kesenangan dan penilaian baik dan buruk.

4. Kebenaran ilmiah, yaitu kebenaran yang obyektif karena adanya relevansi antara pernyataan dan kenyataan.

c. Pendekatan aksiologis, yaitu pendekatan filosofis yang dapat diterapkan ke dalam sosiologi hukum untuk mengkaji gejala sosial dan eksistensi hukum dan berbagai kaidah normatif di masyarakat dalam perspektif fungsi bagi masyarakat. ${ }^{9}$

Dari ketiga pendekatan di atas semuanya mereduksi dari filsapat hukum, namun dari ketiga pendekatan tersebut dapat dikembangkan menjadi lima pendekatan yang berbeda-beda dengan rincian sebagai berikut:

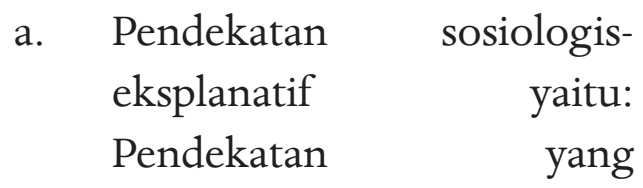
menjelaskan makna-makna hukum yang terdapat dalam kitab-kitab hukum dan kaidah-kaidah hukum yang bersifat dogmatis dengan mengutarakan makna-makna terkstualnya dan menutupi makna kontekstualnya.

\footnotetext{
${ }^{9}$ Beni, Sosiologi Hukum, h. 25-26.
} 
b. Pendekatan ini merupakan linguisitas pemahaman ahli hukum dan soisolog dalam menerjemahkan pasalpasal hukum yang tertulis maupun ugeran-ugeran normatif yang tidak tertulis.

c. Pendekatan sosiologis normatif yaitu: Pendekatan yang tidak sekedar menerjemahkan kaidah hukum yang dogmatis dan pasal-pasal yang tertuang dalam kitab-kitab hukum dan ugeran adatistiadat sosial, namun juga melakukan pengkajian terhadap berbagai latar belakang lahirnya kaidah hukum dan norma sosial yang berlaku di masyarakat.

d. Pendekatan sosiologisinstitusionalistik yakni: Pendekatan yang memandang lembaga hukum atau institusi sosial yang berada bersama masyarakat atau jauh dari jangkuan kehidupan sosial dan karakteristik hukum yang berlaku.

e. Pendekatan sosiologis pluralistikyaitu: Pendekatan yang memahami hukum sebagai kaidah social yang kebenarannya universal, tidak dibatasi oleh wilayah atau lokalitas sosial. Dan pendekatan ini menolak paradigm hukum yang bersifat teritorialis. ${ }^{10}$

Berdasarkan macam-macam bentuk urain pendekatan di atas, makan penyusun lebih memilih untuk menggunakan pendekatan ontologis, karena dengan pendekatan ini maka penyusun dapat memahami hakikat kehidupan masyarakat Desa Mangkung, khusunya cara berpikir masyarakat setempat yang melatarbelakangi sehingga hukum adat kewarisan tersebut masih mampu bertahan di tengah-tengah masyarakat Desa Mangkung hingga saat ini.

\section{Hukum Kewarisan Islam}

a. Pengertian Hukum Kewarisan Islam

Dalambeberapaliteraturhukum Islam ditemui beberapa istilah untuk menamakan hukum waris Islam, seperti Fiqih Mawaris, Ilmu Fara'id, dan Hukum Kewarisan. Adapun pengertian Hukum Waris Islam adalah suatu disiplin ilmu yang membahas tentang harta peninggalan, tentang bagaimana proses pemindahan, siapa saja yang berhak menerima bagian harta peninggalan, serta berapa bagian masing-masing yang akan diperoleh.

Hukum waris Islam juga disebut dengan istilah fara'id yang bentuk jamak dari kata fardh, yang berarti

${ }^{10}$ Ibid., h. 27-28. 
kewajiban atau bagian tertentu. Apabila dihubungkan dengan ilmu, maka menjadi ilmu fara'id yang mengandung arti ilmu untuk mengetahui cara membagi harta warisan orang yang telah meninggal dunia kepada orang yang berhak menerimanya menurut hukum Islam yang sudah tertera dalam AlQur'an. ${ }^{11}$

Sebagaiman yang tertera dalam firman ALLAH SWT yang artinya: Allah mensyari'atkan bagimu tentang pembagian pusaka untuk anakanakmu, yaitu: Bagian seorang anak laki-laki sama dengan bagian dua orang anak perempuan, dan jika anak itu semuanya perempuan lebih dari dua, maka bagi mereka dua pertiga dari harta yang ditinggalkan; Jika anak perempuan itu seorang saja, maka ia memperoleh separuh harta. Dan untuk dua orang ibu-bapak, bagi masing-masingnya seperenam dari harta yang ditinggalkan, jika yang meninggal itu mempunyai anak, jika orang yang meninggal tidak mempunyai anak dan ia diwarisi oleh ibu-bapaknya saja, maka ibunya mendapat sepertiga, jika yang meninggal itu mempunyai beberapa saudara,maka ibunya mendapat seperenam. Pembagian-pembagian tersebut sesudah dipenuhi wasiat

${ }^{11}$ Muhibbin dan Abdul Wahid, Hukum Kewrisan Islam Sebagai Pembaruan Hukum Positif Di Indonesia (Jakarta: Sinar Grafika, 2011), h. 15-16. yang ia buat dan sesudah dibayar hutangnya. Tentang orang tuamu dan anak-anakmu, kamu tidak mengetahui siapa di antara mereka yang lebih dekat banyak manfaatnya bagimu. Ini adalah ketetapan dari Allah. Sesungguhnya Allah Maha mengetahui lagi Maha Bijaksana. ${ }^{12}$

Penjelasan dari ayat di atas adalah, bahwa anak perempuan akan memperoleh harta warisan $2 / 3$ jika lebih dari seorang, jika seorang saja maka harta yang diperolehnya1/2. Sedangkan bagian ibu dan bapak adalah satu perenam $1 / 6$ jika pewaris meninggalkan anak dan beberapa saudara, tetapi jika pewaris tidak meninggalkan anak maka ibu dan bapak akan memperoleh harta warisan $1 / 3$ sesudah dipenuhi wasiat, hutang, yang ditinggalkan oleh pewaris.

b. Asas-Asas Hukum Kewarisan Islam

Dalam pembahasan kewarisan ada lima asas yang berkaitan dengan sifat peralihan harta kepada ahli waris antara lain:

1) Asas Ijbari

Asas ijbari yang dijalankan dalam hukum Islam mengandung arti, bahwa peralihan harta dari seseorang yang telah meninggal kepada

${ }^{12}$ Departemen Agama RI, Al-Qur'an dan Terjemahan (Semarang: Ahmad Tohaputra, 2000), h. 62. 
ahli warisnya yang berlaku dengan sendirinya menurut kehendak Allah SWT tanpa tergantung kepada kehendak atau permintaan dari ahli waris.

2. Asas Bilateral

Asas bilateral mengandung arti bahwa harta warisan akan beralih melalui dua arah. Hal ini berarti bahwa setiap orang yang akan menerima hak kewarisan dari kedua belah pihak garis kerabat, yakni pihak kerabat garis keturunan laki-laki dan garis keturunan perempuan.

3) Asas Individual

Asas individual merupakan aturan hukum Islam yang dimana harta warisan dapat dibagi untuk dimiliki secara perorangan. Masing-masing ahli waris menerima bagiannya secara tersendiri yang sudah ditetapkan dalam Al-Qur'an, tanpa terikat oleh ahli waris yang lain.

4) Asas Keadilan Berimbang

Asas keadilan secara mendasar dapat dikatakan bahwa perbedaan gender tidak menentukan hak kewarisan dalam hukum Islam. Artinya sebagaimana laki-laki, perempuan juga mendaptakan hak yang sama kuat untuk mendapatkan harta warisan.

5. Asas Semata Akibat Kematian
Asas semata akibat kematian mengandung arti bahwa harta seseorang tidak dapat beralih kepada orang lain dengan nama warisanselama yangmempunyai harta masih hidup. ${ }^{13}$

c. Rukun Kewarisan Islam

Rukun merupakan bagian dari permasalahan yang akan menjadi pembahasan, tanpa adanya rukun pembahasan warisan tidak akan sempurna. Dalam masalah kewarisan mempunyai tiga rukun yaitu:

1) Maurus atau harta peninggalan yang ditinggalkan oleh si mayit setelah diambil biaya pemakaman, menjalankan wasiat, dan pelunasan hutang piutang yang berkaitan dengan orang lain ketika si mayit masih hidup. ${ }^{14}$

2) Muwaris atau orang yang telah meninggal dunia yang meninggalkan harta benda yang akan dibagikan kepada keluarganya.

3) Ahli waris atau keluarga yang akan menerima harta warisan dari harta peninggalan si mayit dengan terlebih dahulu dipotong oleh biaya pemakaman, hutang, wasiat.

${ }^{13}$ Amir, Hukum Kewarisan, h. 17.

${ }^{14}$ Otje Salman, Mustofa Haffas, Hukum Waris Islam (Bandung: PT Refika Aditama, 2002), h. 4. 
d. Syarat-Syarat Kewarisan Islam

Syarat-syarat yang harus dipenuhi dalam waris-mewarisi adalah sebagai berikut:

1) Matinya pewaris yang mutlak. Dalam artian seseorang baru bisa disebut muwaris, jika muwarisnya telah meninggal dunia. Kematian muwaris menurut ulama dibedakan menjadi tiga macam yaitu:

a) Mati haqiqy (mati sejati) adalah kematian yang mutlak kebenarannya dan dapat disaksikan oleh panca indra.

b) Mati hukmy (menurut putusan hakim) adalah kematian yang disebabkan adanya putusan dari pihak hakim, baik orangnya masih dalam keadaan hidup maupun sudah mati.

c) Mati taqdiry (menurut dugaan) adalah kematian yang didasarkan pada dugaan yang kuat bahwa orang yang bersangkutan telah mati. ${ }^{15}$

2) Hidupnya ahli waris mutlak harus dipenuhi. Seseorang ahli waris hanya akan mewarisi jika dia masih hidup ketika pewaris meninggal dunia. Masalah yang boleh jadi muncul berkaitan dengan hal ini antara lain

${ }^{15}$ Ibid., h. 5 mafqud, anak dalam kandungan, dan mati bersama.

a) Mafqud adalah hal keberadaan seseorang ahli waris yang tidak diketahui secara pasti keberadaannya, apakah masih hidup atau sudah mati ketika muwaris meninggal dunia.

b) Masalah anak dalam kandungan terjadi pada istri muwaris yang dalam keadaan mengandung ketika muwaris meninggal dunia.

Dalam hal kasus seperti ini maka pembagian ahli waris dapat ditangguhkan sampai anak tersebut dilahirkan.

c) Masalah mati bersama terjadi dalam hal, ketika dua orang atau lebih yang bisa saling mewarisi namun dalam keadaan waktu yang sama mereka mati secara bebarengan. Dalam hal kasus seperti ini maka penetapan keberadaan mereka akan dilakukan dengan memperhatikan kepentingan ahli waris lain yang masih hidup. ${ }^{16}$

3) Tidak ada penghalang dalam waris-mewarisi, ahli waris

${ }^{16}$ Ibid., h. 6. 
baru dapat mewarisi harta peninggalan pewaris jika tidak ada penghalang baginya, seperti karena pembunuhan, dan beda agama. ${ }^{17}$

e. Sebab-Sebab Timbulnya WarisMewarisi

Harta orang yang telah meninggal dengan sendirinya akan beralih kepada orang yang masih hidup yang memiliki hubungan dengan orang yang telah meninggal. Dalam literatur hukum Islam dinyatakan ada empat hubungan yang menyebabkan seseorang bisa menerima harta warisan dari seseorang yang telah mati, yaitu:

1) Adanya hubungan kerkerabatan antara pihak-pihak pewaris dan ahli waris yang memiliki hubungan dekat dengan seseorang karena hubungan darah atau hubungan nasab.

2) Adanya hubungan perkawinan. Suami istri saling mewarisi jika salah seorang dari mereka meninggal dunia dengan ikatan perkawainan masih berlangsung dan perkawinan yang sah menurut hukum Islam.

c) Hubungan wala' (perwalian) akan bisa menerima harta warisan jika orang yang memerdekakannya tidak mempunyai kerabat. ${ }^{18}$

${ }^{17}$ Ibid., h. 7.

${ }^{18}$ Amir, Hukum Kewarisan, h. 174. f. Halangan Dalam WarisMewarisi

Dalam pembahasan sebelumnya telah dijelaskan sebab-sebab adanya hak kewarisan, yaitu hubungan kekerabatan, perkawinan atau perwalian (wala'). Tetapi kewarisan tidak serta merta dapat terwujud, karena boleh jadi ada penghalang dalam waris-mewarisi. Ada dua penghalang dalam mewarisi yaitu:

1) Perbedaan agama yang menghalangi non-muslim untuk mewarisi seseorang yang muslim. Dan sebaliknya muslim tidak bisa mewaris orang nonmuslim.

2) Pembunuhan yang menghalangi seseorang untuk memperoleh warisan dari orang yang dibunuhnya, baik pembunuhan secara perencanaan maupun pembunuhan secara tidak berencana. ${ }^{19}$

g. Golongan Ahli Waris

Berdasarkan besarnya hak yang akan diterima oleh para ahli waris, maka hukum waris Islam membagi dua golongan ahli waris, yaitu golongan ashabul furud dan golongan ashabah.

1) Ashabul furud, yaitu golongangolongan ahli waris yang bagian haknya yang sudah ditentukan oleh Al-Qur'an yaitu: 1/2, 1/3, $1 / 4,1 / 6,1 / 8,2 / 3$.

${ }^{19}$ Ibid., h. 193. 
2) Ashabah, yaitu golongan ahli waris yang bagian haknya tidak tertentu, tetapi mendapatkan sisa dari ashabul furud atau mendapatkan semuanya jika tidak ada golongan ashabul furud. Dalam hal ini para ahli fara'id membedakan ashabah ke dalam tiga macam, yaitu ashabah binnafsi, ashabah bilghairi, dan ashabah ma'alghairi.

a) Ashabah binnafsi adalah kerabat laki-laki yang dipertalikan dengan si pewaris tanpa diselilingi oleh ahli waris perempuan.

b) Ashabah bil-ghairi adalah kerabat perempuan yang memerlukan orang lain untuk menjadi ashabah dan untuk bersama-sama menerima ashabah

c) Ashabah ma'al-ghairi adalah kerabat perempuan yang memerlukan orang lain untuk menjadi ashabah, tetapi orang lain tersebut tidak berserikat dalam menerima ashabah. ${ }^{20}$

h. Bagian Ahli Waris

1) Golongan ahli waris yang mendapatkan harta warisan dengan cara ashabul furud dengan furudul muqaddaroh $1 / 2$ adalah sebagai berikut: a) Anak perempuan jika sendiri.

b) Suami jika tidak bersama anak.

2) Golongan ahli waris dengan furudul muqaddaroh $1 / 3$ adalah sebagai berikut:

a) Ibu jika tidak bersama anak.

b) Nenek jika tidak bersama anak.

3) Ahli waris dengan bagian furudul muqaddaroh $1 / 4$ adalah sebagai berikut:

a) Suamijika mewarisi bersama anak.

b) Istri jika tidak mewarisi bersama anak.

4) Ahli waris dengan furudul muqaddaroh $1 / 6$ adalah sebagai berikut:

a) Bapak jika bersama anak.

b) Ibu dan nenek jika bersama anak.

5) Ahli waris dengan furudul muqaddaroh $1 / 8$ adalah sebagai berikut:

a) Istri jika bersama anak.

6) Ahli waris dengan furudul muqaddaroh $2 / 3$ adalah sebagai berikut:

a) Anak perempuan jika lebih dari seorang.

b) Saudara perempuan jika lebih dari seorang.

${ }^{20}$ Otje, Mustofa, Hukum Waris, h. 51. 
c) Cucu perempuan jika lebih dari seorang. ${ }^{21}$

\section{Analisis Tentang Proses Pelaksanaan Adat Kewarisan Masyarakat Desa Mangkung.}

Pada hakekatnya hukum merupakan suatu realitas sosial, karena mempunyai karakteristik yang selalu merujuk pada realitas sosial. Pertama, hukum menghendaki adanya stabilitas dalam masyarakat. Kedua, hukum sebagaikaedah-kaedah yang mengatur hubungan antar manusia. Ketiga, hukum cenderung untuk mementingkan ketertiban. ${ }^{22}$ Dan merupakan suatu kenyataan bahwa dalam hidup bermasyarakat diperlukan aturan-aturanyangbersifat umum. Karena setiap kepentingan yang ada di dalam masyarakat dipertimbangkan untuk dituangkan dalam aturan yang bersifat umum agar kepentingan-kepentingan tersebut dapat dilindungi. Aturan hukum, baik berupa undang-undang maupun hukum tidak tertulis, berisi aturan-aturan yang bersifat umum yang menjadi pedoman bagi individu bertingkah laku dalam hidup bermasyarakat, baik dalam hubungan dengan sesama individu maupun dalam hubungannya dengan masyarakat. $^{23}$

\footnotetext{
${ }^{21}$ Ibid., h. 58.

${ }^{22}$ Peter Mahmud Marzuki, Pengantar Ilmu Hukum, (Jakarta: Prenadamedia Group. 2008), h. 136
}

${ }^{23}$ Ibid.,h. 138.
Menurut L. J. Van Apeldoorn sebagaimana yang dikutip oleh Ahmad Tholabi Kharlie dalam bukunya, "hukum bertujuan untuk mengatur pergaualan hidup secara damai. Eksistensi hukum sebagai alat yang mendamaikan ini karena dalam setiap individu selalu ada kepentingan pribadi, sehingga jika kepentingan ini diberikan justru akan menyebabkan perselisihan dan konflik. Sedangkan menurut William Even sebagaimana yang dikutip oleh Ahmad Tholabi Kharlie dalam bukunya, "tujuan hukum untuk mengubah tingkah laku, moral, dan kebiasaan masyarakat tertentu. Hukum yang mengodifikasikan moral, kebiasaan atau tingkah laku adalah fungsi pasif dari hukum".

Di sisi yang lain, terdapat fungsi aktif dari hukum yaitu sebagai alat atau unsur utama dalam perubahan sosial, untuk mengodifikasikan tingkah laku masyarakat dan keyakinan mereka, dapat dikategorikan sebagai fungsi aktif dari hukum. Dengan peristilahan lain dikenal dengan hukum sebagai kontrol sosial atau rekayasa sosial. ${ }^{24}$

Hukum sebagai alat rekayasa sosial dimaksudkan bahwa hukum digunakan sebagai sarana atau agen untuk mengubah kondisi masyarakat. Agen ini dapat berupa

${ }^{24}$ Ahmad Tholabi Kharlie, Hukum Keluarga Indonesia (Jakarta: Sinar Grafika, 2013), h.

58. 
perorangan atau sekelompok orang yang mendapatkan kepercayaan dari masyarakat sebagai pemimpin atau lembaga kemasyarakatan. Hukum akan memimpin masyarakat dalam mengubah sistem sosial dan dalam pelaksanaannya yang terkait dengan tekanan-tekanan untuk mengadakan perubahan, atau bahkan mungkin juga menyebabkan perubahan pada lembaga-lembagasosial.Kontrolsosial ini dibutuhkan untuk memelihara peradaban manusia, mulai dari fungsi utamanya mengaturhubungan manusia hingga urusan internal manusia (alamiah) yang menjadi kebutuhan dasar mereka. ${ }^{25}$

Namun seiring dengan proses reformasi dewasa ini, bangsa Indonesia tengah dihadapkan pada suatu potret realita bahwa sistem hukum nasional tidak berlaku efektif di tengah masyarakat. Hal ini tidak bisa lepas dari pengaruh kondisi masyarakat yang begitu pluralistis dengan hukum adat merupakan akibat rendahnya mutu dan penetrasi pendidikan hukum itu sendiri. Selain itu, masyarakat yang cendrung tumbuh dengan paradigma hukum adatnya secara tradisional, lebih banyak menerima informasi dan komunikasi yang intens daripada pengetahuan hukum nasionalanya. ${ }^{26}$

\footnotetext{
${ }^{25}$ Ibid., h. 59.

${ }^{26}$ Juhaya S. Praja, Teori Hukum Dan Aplikasinya, (Bandung: CV Pustaka Setia, 2011), h.55.
}

Istilah hukum adat diperkenalkan di kalangan banyak orang yang lazimnya mereka sebut "adat" saja. Kata adat berasal dari bahasa arab yang berarti kebiasaan. Berdasarkan hal ini, dapat dilihat dari perkembangan hidup manusia yang diberi akal pikiran oleh Tuhan dalam berprilaku. Dan dengan prilaku yang secara terus menerus dilakukan perorangan menimbulkan kebiasaan pribadi. Karena dalam diri manusia telah melekat sebuah behavior yang dapat dilihat dari gerak motoris, persepsi, maupun fungsi kognitifnya yang membentuk sebuah totalitas diri sebagai individu. Dari prilaku yang terus-menerus dilakukan perorangan akan menimbulkan kebiasaan pribadi. Adanya aksi dan reaksi yang terpolarisasi dari hubungan timbal balik antara individu yang satu dan yang lainnya, akan membentuk sebuah interaksi sosial. Tata alur inilah yang menunjukan proses lahirnya adat-istiadat yang menjadi hukum dalam masyarakat. ${ }^{27}$

Hukum adat memiliki ciri khas, yang dimana hukum adat cendrung bersifat tradisional dalam arti bahwa hukum adat berakar dari kehendak nenek moyang yang diagungkan. Pada sisi lain hukum adatpun dapat berubah dan menyesuaikan diri dengan kondisi-kondisi tertentu

${ }^{27}$ Suriyaman Mustari, Hukum Adat Dahulu, Kini, Dan Akan Datang, (Jakarta: Preniadamedia Group, 2014), h. 2. 
dari perkembangan masyarakat. Perubahan ini biasanya terjadi bukan karena adanya penghapusan secara resmi, melainkan karena adanya perubahan kondisi, tempat dan waktu. $^{28}$

Pada hakekatnya hukum adat mengutamakan adanya musyawarah dan mufakat, baik di dalam keluarga, hubungan kekerabatan, ketetanggaan memulai suatu pekerjaan maupun dalam mengakhiri pekerjaan antara yang satu dan yang lainnya, diutamakan jalan penyelesaiannya secara rukun dan damai dengan musyawarah dan mufakat, dengan saling memaafkan tanpa harus terburu pertingkaian langsung dibawa atau disampaikan ke pengadilan negara. Dan corak musyawarah dan mufakat ini dalam penyelesaian perselisihan biasanya didahului oleh adanya semangat i'tikad baik, adil, dan bijaksana dari orang yang dipercaya sebagai penengah perkara atau semangat dari majelis permusyawaratan adat. ${ }^{29}$

Salah satunya perkara warisan yang dimana aturan-aturan atau norma hukum yang mengatur atau menetapkan bagaimana harta peninggalan atau warisan diteruskan atau dibagi-bagi kepada ahli waris dari generasi ke generasi. Proses peralihan harta ini sesungguhnya

\footnotetext{
${ }^{28}$ Ibid,. h. 16.

${ }^{29}$ Dewi Wulansari, Hukum Adat Indonesia, (Bandung: PT Rafika Aditama, 2014), h. 21.
}

sudah dapat dimulai semasa pemilik harta (muwaris) masih hidup serta proses tersebut dapat berlanjut terus-menerus hingga keturunannya masing masing. ${ }^{30}$

Bila ditilik tentang sifat hukum waris adat ini, terlihat bahwa sifat hukum waris adat bercorak komunal dari alam pikiran tradisional Indonesia. Oleh karena itu, hukum waris adat memiliki perbedaan dengan hukum-hukum waris barat dan hukum waris Islam. Hukum waris adat dapat meletakan dasar kerukunan pada proses pelaksanaan pembagiannya. Dan hukum waris adat dalam pelaksanaan pembagiannya dapat ditunda untuk waktu yang cukup lama atau hanya sebagian yang dibagi. Maka dapat diketahui bahwa hukum waris adat sangat erat hubungannya dengan sifat-sifat kekeluargaan dari masyarakat yang bersangkutan beserta pengaruhnya pada harta kekayaan yang ditinggalkan yang berada dalam masyarakat itu. ${ }^{31}$

Sepertihalnya hukum waris adat masyarakat Desa Mangkung. Kalau dianalisa perkembangan hukum adat kewarisannya sampai saat ini masihdipertahankan oleh masyarakat setempat. Karena masyarakat setempat masih tergolong sangat kental dalam menerapkan hal-hal yang menyangkut persoalan tentang

${ }^{30}$ Ibid,. h. 71.

${ }^{31}$ Ibid,. h. 73 
adat-istiadat. Hal tersebut tidak bisa lepas dari pengaruh tatanan lingkungannya yang merupakan komunitas masyarakat lokal yang memiliki ciri khas masih memegang erat kebiasaan-kebiasaan lama tanpa harus mempertimbangkan apakah kebiasaan-kebiasaan tersebut dapat menyesuaikan dengan keadaan masyarakat yang mengalami perubahan kehidupan dan aktifitas yang lebih maju. Dan bisa dikatakan bahwa hal tersebut yang menyebabkan adat-istiadat masyarakat Desa Mangkung belum mampu untuk dimanimalisirkan, karena adat atau norma-norma tersebut merupakan sesuatu yang sudah melekat dalam kehidupan masyarakatnya. Khsususnya tentang adat pembagian harta warisan yang sampai saat ini masih diterapkan oleh masyarakat setempat.

Adat kewarisan ini mampu bertahan dalam tatanan kehidupan masyarakat Desa Mangkung, karena adat-istiadat tersebut sampai saat ini masih dipertahankan oleh masyarakat setempat, dan bisa dikatakanbahwasecara tidaklangsung penerapan dari adat kewarisan yang dilakukan oleh masyarakat mampu memberikan suatu pemahaman, pelajaran kepada individual lainnya yang akan mengakibatkan terjadinya peniruan dalam tatanan kehidupan bermasyarakat yang berada dalam satu komunitas. Sehingga adat kewarisan tersebutpun secara tidak langsung akan tetap diterapkan dari generasi ke genarasi berikutnya.

"Masyarakat Desa Mangkung bisa dikatakan rata-rata dalam menyelesaikan masalah harta peninggalan (warisan) lebih dominan untuk memeilih jalan penyelesaian yang lebih cepat. Dan hal tersebut dapat diperoleh dengan cara menggunakan hukum adat, karena sudah menjadi corak dari masyarakat Desa Mangkung, yang apabila akan menyelesaikan suatu persoalan lebih-lebih persoalan yang menyangkut tentang adatistiadat musyawarah dan mufakat merupakan jalan pertama yang harus ditempuhnya. Karena masyarakat setempat berpandangan bahwa cara musyawarah dan mufakat merupakan cara utama untuk menghindari terjadinya perselisihan antara keluarga.

Kesepakatan dari para ahli waris harus benar benar tulus dan ikhlas dari hati nurani. Karena dengan adanya kesepakatan dari masing-masing para ahli waris, maka keutuhan dan kerukunan dalam berkeluarga akan tetap terjaga tanpa harus ada perselisihan. Karena pada dasarnya masyarakat setempat berpandangan bahwa kerukunan dalam kekeluargaan yang paling diutamakan. Hal tersebut yang menyebabkan masyarakat setempat lebih dominan untuk menggunakan 
hukum adat untuk menyelesaikan sengketa menyangkut tentang pembagian harta warisan". ${ }^{32}$

Pada umumnya masyarakat Desa Mangkung akan melakukan pembagian apabila salah satu dari golongan ahli waris laki-laki menuntut agar harta warisan tersebut untuk dibagikan karena kebutuhan dari ahli waris tersebut. Dalam pelaksanaannya jika sebagian ahli waris ada yang belum dewasa dan belum mapan maka hak bagiannya menjadi harta warisan gantungan yang akan dikuasai oleh ibunya atau saudaranya yang diserahkan untuk mengurus/mengelolanya untuk sementara waktu sampai ahli waris tersebut dewasa dan mapan untuk memanfaatkan harta warisan tersebut. $^{33}$

\section{Analisis Tentang Alasan Masyarakat Desa Mangkung Menggunakan Hukum Adat Dalam Melakukan Pembagian Harta Warisan}

\section{Kolektifitas Sosial}

Hidup bermasyarakat merupakan modus survival bagi manusia, artinya hanya dengan hidup bermasyarakat manusia dapat melangsungkan hidupnya. Hal ini berarti manusia tidak mungkin

${ }^{32}$ Darmawan Tokoh Adat, Wawancara di Desa Mangkung, Rabu, Tanggal 27 Juli 2016.

${ }^{33}$ Darmawan Tokoh Adat, Wawancara di Desa Mangkung, Rabu, Tanggal 27 Juli 2016. hidup secara atomistis dan soliter. Tidak dapat disangkal bahwa secara kodrati manusia memang makhluk bermasyarakat. Mengingat manusia kodratnya sebagai makhluk sosial, untuk dapat melangsungkan hidupnya dan eksetensinya sebagai manusia, dan manusia mengembangkan sarana yang bersifat imaterial yang dapat menjadi perekat dalam hidup bermasyarakat. Oleh karena adanya pranata-pranata yang timbul karena adanya moral dalam masyarakat. ${ }^{34}$

Dalam masyarakat primitif, prilaku anggota masyarakat memanifestasikan keteraturan lahiriah tertentu, terutama dalam hubungannya dengan sesamanya. Keteraturan tersebut tampaknya dikondisikan secara organisasi dan merupakan ciri manusia yang paling primer. Dari merekalah berasal ide tentang suatu norma yang seharusnya ditaati. Hal tersebut menunjukkan bahwa dalam berinteraksi dengan sesamanya, prilaku seseorang itu dipengaruhi oleh nilai atau norma tertentu yang berlaku dalam masyarakatnya serta kebudayaannya. ${ }^{35}$

Nilai dan norma (adatistiadat, kebiasaan, kaidah) sangat erat kaitannya satu sama lain. Norma sebagai petunjuk arah untuk menentukan antara prilaku yang

\footnotetext{
${ }^{34}$ Peter Mahmud, Pengantar Ilmu, h. 41.

${ }^{35}$ Elly M. Setiadi, Usman Kolip, Pengantar Sosiologi, (Bandung: Premedia Group, 2010), 41.
} 
boleh dilakukan dan yang dilarang. Sedangkan nilai merupakan merupakan cita-cita kehdupan kelompok itu sendiri, sebab nilai merupakan konsep tentang sesuatu yang baik, layak, patut, pantas, yang menjadi cita-cita bersama. Namun kebutuhan tersebut tidak akan terpenuhi jika manusia hidup berkelompok. Sebab tidak ada bayi baru lahir yang langsung memiliki kemampuan mempertahankan hidup tanpa peran orang tua dan lingkungan. Karena hal yang tidak bisa dihindari oleh setiap individ adalah tidak ada satupun individu yang memiliki kemampua untuk memenuhi kebutuhan hidupnya tanpa hidup dalam kelompok. ${ }^{36}$

Adat-istiadatatau kebiasaanyang ada di masyarakat dapat dikatakan sebagai ruh dalam interaksi sosial. Hal ini dikarenakan kebiasaan yang ada di masyarakat menjadi sebuah identitas dari kelompok sosial tertentu atau ciri dari masyarakat tertentu. Kebiasaan pada dasarnya menunjukkan suatu gejala dalam perilaku seseorang untuk bertindak secara teratur. Dari kebiasaan-kebiasaan seseorang ini dapat berpengaruh pula pada kehidupan seseorang lainnya dan dapat menjadi norma atau patokan dalam kehidupan bermasyarakat. ${ }^{37}$

${ }^{36}$ Ibid., h. 43.

${ }^{37}$ Kajian Sosiologi Hukum Dalam Penegakan Hukum Perkawinan Pada Perkawinan Anak Anak http: / / astriboy.blogspot.co.id (Diakses, 7 Juli 2016).
Sebagaimana halnya yang terjadi di kalangan masyarakat Desa Mangkung, yang dimana masyarakatnya dalam bertingkah laku tidak akan menyimpang dari keadaan yang sudah ada yang timbul akibat dari prilaku orangorang terdahulu. Maka dapat dikatakan bahwa masyarakat Desa Mangkung sudah menyatu dengan keadaan yang ada di dalam tatanan lingkungannya. Lebih-lebih hal yang menyangkut tentang persoalan adatistiadat yang merupakan landasan utama masyarakat setempat dalam bertingkah laku dalam kehidupan bermasyarakat. Prilaku dari Masyarakat Desa Mangkung inipun dapat mencerminkan, bahwa masyarakat setempat masih menanam sifat-sifat kebersamaan dalam upaya untuk tetap menerapkan adat-istiadat yang diwariskan nenekmoyang mereka. Karena masyarakat setempat lebih mengutamakan kepentingan bersama dari pada kepentingan pribadi. Kepentingan bersama dalam artian bahwa masyarakat setempat berusaha untuk tetap menjalankan adatistiadat secara bersama-sama, tanpa mempertimbangkan terlebih dahulu apakah adat-istiadat tersebut sudah memenuhi rasa keadilan dalam penerapannya. Karena masyarakat setempat meyakini bahwa adatistiadat tersebut sudah sejalan dengan moral dan kebiasaan dari 
masyarakat setempat. Khususnya adat-istiadat tentang pembagian harta warisan.

\section{Menjaga Peninggalan Le- luhur}

Manusia dengan kebudayaan merupakan kesatuan yang tidak terpisahkan, sementara itu pendukung kebudayaan adalah makhluk manusia itu sendiri. Dan sekalipun makhluk manusia akan mati, tetapi kebudayaan yang dimilikinya akan diwariskan pada keturunannya, demikian seterusnya. Pewarisan kebudayaan tidak selalu terjadi secara vertikal atau kepada anak cucu mereka, melainkan dapat pula secara horizontal yaitu manusia yang satu dapat belajar kebudayaan dari manusia lainnya. Kebudayaan juga merupakan keseluruhan yang kompleks yang di dalamnya terdapat pengetahuan, kepercayaan, kesenian moral, hukum, adat-istiadat. ${ }^{38}$

Maka dapat dikatakan
bahwasanya, tidak ada suatu masyarakat yang tanpa kebudayaan, karena setiap masyarakat betapaun sederhananya pasti memiliki nilainilai dan norma-norma atau kaidahkaidah. Salah satu norma yang ada dalam masyarakat yang terwujud dari perikelakuan masyarakat yang dilakukan secara berulang-ulang dalam pola yang sama, yang disebut

\footnotetext{
${ }^{38}$ Hari Poerwanto, Kebudayaan Dan Lingkungan Dalam Perspektif Antropologi, (Yogyakarta: Pustaka Belajar, 2005), h. 50.
}

dengan norma atau hukum adat. Dengan demikian, norma hukum adat merupakan bagian dari normanorma masyarakat (norma sosial). ${ }^{39}$

Berbicara masalah budaya, tidak akan bisa terlepas dari persoalan persoalan nilai kearifan lokal karena nilai-nilai kearifan lokal mengandung nilai-nilai adi luhung peninggalan orang terdahulu yang memuat tentang aturan-aturan dan norma-norma sebagai pijakan dalam bertingkah laku dan bertutur sapa. Dan kearifan budaya adalah suatu terminilogi yang diberikan bagi keseluruhan nilai-nilai maupun sistem kehidupan masyarakat leluhur di masa lampau hal ini terbukti secara signifikan masih terus hidup memberikan roh dan nilai-nilai baru di era globalisasi, asalkan diaplikasikan dalam kehidupan bermasyarakat secara teguq (kuat dan utuh), lurus dan jujur, bersungguh sungguh, dan penuh rasa kasih sayang. ${ }^{40}$

Seperti halnya yang dilakukan oleh masyarakat Desa Mangkung dalam menghadapi pola pikir dan kehidupanyanglebihmajuupayauntuk mempertahankan adat-istiadat yang diwariskan nenek-moyang mereka. Yang dimana masyarakat setempat melakukan suatu pengajaran tentang

${ }^{39}$ Dewi Wulansari, Hukum Adat, h. 12.

${ }^{40}$ Warni Djuwita, Psikologi Perkembangan Stimulasi Aspek Perkembangan Anak Dan Nilai Kearifan Lokal Melaui Permainan Tradisional Sasak, (Mataram : LKIM Lembaga Kajian Islam Dan Masyarakat, 2011), h.119 
begitu pentingnya adat-istiadat dalam kehidupan bermasyarakat. Sehingga masyarakat setempat dapat menyadari dan merasa bersamasama bertanggung jawab untuk menjaga warisan nenek-moyang mereka dalam kehidupan bersosial. Khususnya adat-istiadat tentang pembagian harta warisan.

Di satu sisi masyarakat setempat masih menjaga pola pikir dan paradigma yang sifatnya mengutamakan kebersamaan untuk sama-sama mewujudkan agar kebiasaan-kebiasaan tersebut untuk tetap diterapkan dan dijaga kearifannya. Pola pikir tersebut tidak bisa lepas dari pengaruh lingkungan yang didiaminya semenjak dilahirkan, dan yang didiami oleh orang tuanya, sampai nenek moyang mereka. Maka dapat dikatakan masyarakat Desa Mangkung untuk meninggalkan tanahkelahairannya tidak akan mudah untuk dilakukannya, termasuk untuk meninggalkan aturan-aturan/normanorma yang berlaku di dalam tatanan lingkungan hidupnya.

Masyarakat Desa Mangkung juga masih merasa terikat dalam suatu ketertiban berdasarkan kepercayaan bahwa mereka berasal dari satu keturunan yang sama. Dalam artian masyarakat setempat tergolong dalam satu komunitas yang bersangkutan, karena meyakini bahwa mereka berasal dari satu keturunan (nenekmoyang) yang sama yang harus membuatnya tunduk dan patuh dengan peraturan-peraturan yang diwariskan nenek moyang mereka tanpa harus mempertimbangkan terlebih dahulu apakah kaidahkaidah yang terdapat dalam adatistiadat/kebiasaan-kebiasaan tersebut sudah bisa memenuhi rasa keadilan dalam menerapkannya. Karena bagaimanapun yang diutamakan oleh masyarakat setempat adalah kebersamaandalammempertahankan keutuhan adat-istiadat tersebut.

\section{Menghindari Perselisihan}

Peranan hukum adat berfungsi sebagai pengendalian sosial yangpada dasarnya merupakan pengekangan atau pembatasan terhadap satu tingkah laku dan pembetulan tingkah laku dari individu maupun kelompok yang pada dasarnya sebagai bentuk usaha untuk satu tata nilai atau kaidah kaidah agar tercipta satu kedamaian atau ketentraman di dalam masyarakat. Oleh kaena itu, pengendalian sosial juga merupakan usaha untuk menilai tingkah laku karena perbaikan itu berangkat dari penilaian yang diberikan oleh satu kelompok kepada individu atau sebaliknya.

Penilaian inilah kemudian disebut sesuai atau tidak sesuai dengan nilai nilai atau kaidah-kaidah yang ada dan menjadi panutan bersama. ${ }^{41}$ Dalam masyarakat

\footnotetext{
${ }^{41}$ Dewi Wulansari, Hukum Adat, h. 160.
} 
terdapat norma-norma yang mengatur kehidupannya, dengan adanya norma-norma masyarakat bertindak laku sesuai aturan yang telah ada, sehingga tidak sertamerta akan bertindak laku sesuai kehendak dirinya. Dalam masyarakat apabila ingin menjaga hubungan antar manusia di dalam suatu masyarakat terlaksana sebagaimana yang diharapkan. Maka dirumuskan norma-norma masyarakat. Mulamula norma tersebut terbentuk secara tidak sengaja. Namun lama kelamaan norma-norma tersebut tersebut dibuat secara sadar.

Norma-norma yang ada di dalam masyarakat mempunyai kekuatan mengikat yang berbedabeda. Ada norma yang lemah, yang sedang sampai yang kuat daya ikatnya. Pada yang terakhir, umumya anggota-anggota masyarakat pada tidak berani melanggarnya. ${ }^{42}$

Sebagaimana adat-istiadat yang ada di kalangan masyarakat Desa Mangkung, yang diaman masyarakat Desa Mangkung apabila akan menyelesaikan suatu persoalan, khususnya menyangkut persoalan pembagian harta warisan. Masyarakat setempat tidak akan keluar dari kaidah-kaidah/norma-

\footnotetext{
${ }^{42}$ Makalah Suhartini, Kajian Kearifan Lokal Masyarakat Dalam Pengelolaan Sumber Daya Alam Dan Lingkungan. Mahasiswa Jurusan Biologi FMIPA Universitas Negeri Yogyakarta. h. 8
}

norma yang berlaku dalam tatanan kehiduapnnya. Karena masyarakat setempat meyakini bahwa normanoram tersebut merupakan suatu landasan atau motivasi dalam bertindak, sehingga bisa dikatakan bahwa prilaku masyarakat Desa Mangkung merupakan suatu pencerminan dari nilai-nilai adatistiadat tersebut. Khususnya cara berprilaku dalam menyelesaikan persoalan pembagian harta warisan.

Masyarakat Desa Mangkung selain meyakini bahwa norma norma/adat-istiadat tersebut merupakan suatu pedoman dalam berprilaku, masyarakat setempat juga meyakini bahwa adat-istiadat tersebut memiliki nilai-nilai luhur yang bisa memberikan kebaikan, kedamaian, dan kesejahteraan bagi kehidupan masyarakat setempat. Seperti halnya dalam menyelesaikan persoalan yang menyangkut tentang harta peninggalan, yang dimana landasan utama dalam penyelesaiannya yakni dengan cara bermusyawarah dan mufakat, karena dengan cara musyawarah dan mufakat maka perselisihan dalam kekeluargaan akan dapat terhindari.

\section{E. PENUTUP}

\section{a. Kesimpulan}

Berdasarkan dari uraian bab-bab sebelumnya, maka penyusun dapat menyimpulkan sebagai berikut: 
1. Pelaksanaan pembagian harta warisan di kalangan masyarakat Desa Mangkung rata-rata lebih dominan menggunakan hukum adat,yangdimanapembagiannya dilakukan apabila salah satu dari ahli waris menuntut untuk harta warisaanya dibagikan. Sedangkan Dalam proses pembagiannyamasyarakatharus menempuh jalan musyawarah mufakat, karena prinsip dasar masyarakatsetempatkedamaian harus tetap diutamakan selama proses pembagiannya sampai selesai, dan masyarakat setempat meyakini hal tersebut hanya bisa didapatkan dengan cara musyawarah mufakat.

Sedangkan dalam pembagiannya, harta warisan yang sifatnya terbagi hanya diberikan kepad ahli waris anak laki-laki, dan harta warisan yang sifatnya tidak terbagi hanya diberikan kepada ahli waris laki-laki paling kecil untuk dimiliki secara pribadi. Sedangkan anak perempuan hanya diperbolehkan membawa harta yang ada di anggota badan, seperti kalung, cincin dan giwang yang tidak termasuk dalam harta bersama dalam keluarga, melainkan hak milik pribadi secara sah.

2. Berdasarkan hasil penelitian sebelumnya. Ada tiga alasan masyarakat Desa Mangkung menggunakan adat kewarisan diantaranya adalah sebagai berikut:

1. Kolektifitas Sosial: Pada umunya masyarakat Desa Mangkung dalam menggunakan adat kewarisan hanya mengikuti dan menjalani keadaan yang sudah berlaku di tatanan lingkungannya, tanpa harus mempertimbangkan terlebih dahulu apakah adat kewarisan terebut sudah memenuhi rasa keadilan dalam menerapkannya. Karena masyarakat setempat meyakini bahwa adat-istiadat tersebut sudah sejalan dengan moral dan kebiasaan dari masyarakat setempat. Khususnya adat tentang pembagian harta warisan.

2. Menjaga Peninggalan Leluhur: Rata-rata dari masyarakat Desa Mangkung masih memiliki pola pikir dan paradigm yang sangat kental dalam mempertahankan halhal yang menyangkut persoalan tentang adat istiadat, khususnya tentang adat kewarisan. Karena masyarakat setempat berpandangan bahwa 
adat-istiadat tersebut merupakan warisan dari nenek moyang yang harus tetap dipertahankan. Dan hal tersebut sudah menjadi ciri khas dari masyarakat Desa Mangkung yang merupakan masyarakat lokal yang masih memegang kebiasaan-kebiasaan lama.

3. Menghindari Terjadinya Perselisihan: Masayrakat Desa Mangkung pada umumnya berpandangan bahwa, aturan-aturan atau norma-norma yang terkandung dalam adat kewarisan tersebut memiliki nilai-nilai luhur yang bisa memberikan kebaikan, kedamaian, kesejahteraan bagi masyarakatnya. Karena dalam proses penyelesaiannya musyawarah dan mufakat merupakan jalan utama yang ditempuhnya. Musyawarah dan mufakat ini dilakukan untuk mendapatkan kesepakatan dari para ahli waris untuk menghindari terjadinya silang sengketa dalam kerukunan berkeluarga.

\section{b. Saran-Saran}

1. Bagi Tokoh Agama: Bagi tokoh agama hendaklah untuk lebih memperhatikan perkembangan hukum yang berlaku di masyarakat. Khususnya adat tentang pembagian harta warisan, sehingga tokoh agama dapat menyampaikan kepada masyarakat hukum yang berkaitan dengan pembagian harta warisan yang sudah dijelaskan dalam kaidah hukum Islam.

2. Bagi Tokoh Adat: Hendaklah adat-istiadat tersebut diusahakan untuk dimanimalisirkan, khususnya tentang adat kewarisan. Karena bagaimanapun hukum Islam haruslah didahulukan daripada hukum adat, terlebih-terlebih masyarakat Desa Mangkung yang dimana rata-rata memiliki satu keyakinan dalam beragama, yakni agama Islam.

3. Bagi Masyarakat: Apabila akan menyelesaikan persoalan menyangkut tentang harta peninggalan hendaklah harta warisan tersebut terlebih dahulu dibagikan sesuai dengan kaidah yang sudah dijelaskan dalam hukum Islam, dan setelah melakukan pembagian sesuai dengan kaidah yang sudah dijelakskan dalam hukum Islam, dan kalau memang ada sebagian dari para ahli waris yang merelakan hak bagiannya, maka hendaklah memilih dengan cara menghibahkan hak 
bagiannya tersebut. Tanpa harus mendahului hukum adat dan membelakangi kaidah hukum Islam.

\section{DAFTAR PUSTAKA}

Amir Syarifuddin, Hukum Kewarisan Islam (Jakarta: Prenada Media, 2014)

Ahmad Tholabi Kharlie, Hukum Keluarga Indonesia (Jakarta: Sinar Grafika, 2013)

Beni Ahmad Saebani, Sosiologi Hukum (Bandung: Cv Pustaka Setia, 2007)

Dewi Wulansari, Hukum Adat Indonesia, (Bandung: PT Rafika Aditama, 2014),

Departemen Agama RI, Al-Qur'an dan Terjemahan (Semarang: Ahmad Tohaputra, 2000

Elly M. Setiadi, Usman Kolip, Pengantar Sosiologi, (Bandung: Premedia Group, 2010

Idris Ramulyo, Perbandingan Hukum Kewarisan Islam di Pengadilan Agama dan Kewarisan Menurut ndang-Undang Hukum Perdata (BW) di Pengadilan Negeri (Jakarta: Pedoman Ilmu Jaya, 1992

Juhaya S. Praja, Teori Hukum Dan Aplikasinya, (Bandung: CV Pustaka Setia, 2011

Keluarga Besar Peradilan Agama (KBPA), "Hukum Kewarisan
Menurut Hukum Perdata (BW) dan KHI",ttp:/ / www.uinjkt. blogspot.com. (Diakses, 11 April 2006

Kajian Sosiologi Hukum Dalam Penegakan Hukum Perkawinan Pada Perkawinan Anak Anak http: / / astriboy.blogspot.co.id (Diakses, 7 Juli 2016).

Muhibbin dan Abdul Wahid, Hukum Kewrisan Islam Sebagai Pembaruan Hukum Positif Di Indonesia (Jakarta: Sinar Grafika, 2011

Otje Salman, Mustofa Haffas, Hukum Waris Islam (Bandung: PT Refika Aditama, 2002

Peter Mahmud Marzuki, Pengantar Ilmu Hukum, (Jakarta: Prenadamedia Group

Suriyaman Mustari, Hukum Adat Dahulu, Kini, Dan Akan Datang, (Jakarta:Preniadamedia Group, 2002

Warni Djuwita, Psikologi Perkembangan Stimulasi Aspek Perkembangan Anak Dan Nilai Kearifan Lokal Melaui Permainan Tradisional Sasak, (Mataram : LKIM Lembaga Kajian Islam Dan Masyarakat, 2011

Zainuddin, Sosiologi Hukum, (Jakarta: Sinar Grafika, 2012 